\title{
Factors affecting the numbers of expected viable lactic acid bacteria in inoculant applicator tanks
}

\author{
M. C. Windle and L. Kung Jr. ${ }^{1}$ \\ Department of Animal and Food Sciences, University of Delaware, 531 S College Ave., Newark 19716
}

\begin{abstract}
The application of correct numbers of viable microorganisms to forages at the time of ensiling is one of the most important factors affecting the probability of a beneficial effect from an inoculant. The objective of this study was to determine relationships between numbers of expected lactic acid bacteria (LAB) from silage inoculants in application tanks and various factors that might affect their viability. The $\mathrm{pH}$ and temperature of inoculant-water mixes were measured in applicator tanks $(\mathrm{n}=53)$ on farms in Wisconsin, Minnesota, South Dakota, and California during the corn harvest season of 2012. Samples were collected on-farm and plated on de Man, Rogosa, and Sharpe agar to enumerate LAB and establish the number of viable LAB $(\mathrm{cfu} / \mathrm{mL})$. Expected numbers of LAB were calculated from the minimum label guarantees for viable bacteria and mixing rates with water. In addition, the $\mathrm{pH}$ of the inoculantwater mixes at sampling, the ambient temperature at sampling, and the length of time that the samples had been in the tank were measured and obtained. The log difference between the measured and expected numbers of LAB was calculated and expressed as $\Delta \mathrm{M}-\mathrm{E}$ in log scale. Ambient temperature at sampling had no relationship with time in the tank or $\Delta \mathrm{M}-\mathrm{E}$. Most (83\%) of the inoculants had been mixed with water in the applicator tanks for $<10 \mathrm{~h}$. For these samples, a negative linear correlation $\left(\mathrm{R}^{2}=0.36\right)$ existed between time that the inoculant-water mixes were in the applicators tanks and $\Delta \mathrm{M}-\mathrm{E}$. The $\mathrm{pH}$ of the inoculant-water mixes was also negatively correlated $\left(\mathrm{R}^{2}=0.28\right)$ with time in the applicator tank, but $\mathrm{pH}$ was not related to $\Delta \mathrm{M}-\mathrm{E}$. The temperatures of the inoculant-water mixtures were negatively correlated with $\Delta \mathrm{M}-\mathrm{E}\left(\mathrm{R}^{2}\right.$ $=0.39$ ). Seven of 8 samples whose $\Delta \mathrm{M}-\mathrm{E}$ were at least -0.95 or more lower than expected (equivalent of about 1 or more log concentration less than expected)
\end{abstract}

Received January 11, 2016.

Accepted June 23, 2016.

${ }^{1}$ Corresponding author: lksilage@udel.edu had water temperatures above $35^{\circ} \mathrm{C}$. These data support our previous laboratory findings and suggest that high temperatures of inoculant-water mixes have the potential to negatively affect the final application rate of some inoculants, which may affect their overall effectiveness to improve silage fermentation.

Key words: lactic acid bacteria, inoculant, silage

\section{INTRODUCTION}

Lactic acid bacteria (LAB) are commonly used as inoculants to improve the fermentation and aerobic stability of silages (Stokes and Chen, 1994; Muck, 2010). The microbial inoculants are typically mixed with water, held in tanks on the forage harvester, and applied to forages before ensiling. To maximize their potential effectiveness, the correct amount of viable organisms must be evenly applied and distributed onto the forage mass during application. Utilizing inoculants that meet minimum label guarantees for live LAB, correct mixing and application, and proper storage before and during application can ultimately influence the probability of an inoculant affecting the ensuing fermentation. The temperature of the inoculant-water mix and the length of time that the mix is held in the applicator tank could affect the actual application rate of the additive. In the field, inoculant tanks have the potential to absorb heat from solar radiation and from the forage harvester. In a laboratory study, Mulrooney and Kung (2008) reported that the viability of several microbial inoculants was markedly decreased when the temperature of the water that they were in was above $35^{\circ} \mathrm{C}$. Thus, the primary objective of this study was to measure the number of LAB in inoculant tanks in the field and determine if a relationship existed between the expected numbers of viable bacteria in the tanks and the temperature of the water that they were stored in or the length of storage time.

\section{MATERIALS AND METHODS}

Samples of the inoculant-water mixtures were collected from 53 applicator tanks in Wisconsin, Minnesota, 
South Dakota, and California during the normal corn silage harvest season in September 2012. Temperature ranged from 18.3 to $36^{\circ} \mathrm{C}$ and humidity ranged from 27 to $96 \%$. Samples were collected from a variety of different types of tanks $[6$ tanks built into the chopper 2 barrel tanks used with an Ag Bagger (Ag Bag Systems, St. Nazianz, WI), 2 Pioneer low-volume applicators (DuPont Pioneer, Johnston, IA), 5 high-volume, chopper-mounted, clear applicators (manufacturers unknown), and 38 Dohrmann low-volume applicators (Dohrmann Enterprises, Waite Park, MN)]. Choppers were both self-propelled and pull-type choppers. A variety of inoculants from various manufacturers were used (Table 1). To sample the inoculant-water mixes from the applicator tanks, the contents of the tanks were thoroughly mixed for about 20 to $30 \mathrm{~s}$, and samples were collected with a sterile pipette and placed in a sterile collection cup. Tenfold serial dilutions were prepared aseptically in sterile $1 / 4$ strength Ringers solution (Oxoid BR0052G; Oxoid Ltd., Cambridge, UK). Serial dilutions were spread-plated within 5 min of collection on prepoured de Man, Rogosa, and Sharpe agar (CM 3651,
Oxoid, Basingstoke, UK) for the enumeration of LAB. Plates were incubated at room temperature $\left(20-23^{\circ} \mathrm{C}\right)$ for 3 to $5 \mathrm{~d}$ before enumeration of LAB. To account for differences in inoculant concentrations, mixing rates, application rates, and minimum label guarantees, numbers of LAB are reported as the difference between the measured bacterial counts in the tank and the expected bacterial counts calculated from mixing rate and minimum label guarantee of LAB for the various products. This difference was denoted as $\Delta \mathbf{M}-\mathbf{E}(\log \mathrm{cfu} / \mathrm{mL})$. This calculation was made using the original inoculant containers to obtain the minimum label guarantee for LAB. A theoretical value of 0 for $\Delta \mathrm{M}-\mathrm{E}$ was the result of the measured concentration of LAB from the application tank matching the theoretical calculation based on minimum label guarantee and mixing rate with water. A $\Delta \mathrm{M}-\mathrm{E}$ value greater than 0 would be obtained if the determined concentration of LAB was greater than expected based on minimum label guarantee, and values less than 0 would mean that determined values were less than expected. Calculation of $\Delta \mathrm{M}-\mathrm{E}$ was made to eliminate bias because the final applica-

Table 1. The inoculants, distributors, and bacterial species that were enumerated in various inoculant tanks

\begin{tabular}{|c|c|c|c|}
\hline $\begin{array}{l}\text { No. of } \\
\text { samples }\end{array}$ & Inoculant name & Distributor or manufacturer & Bacterial species \\
\hline 3 & $11 \mathrm{C} 33$ & Pioneer, Johnston, IA & $\begin{array}{l}\text { Lactobacillus buchneri } \\
\text { Lactobacillus plantarum } \\
\text { Enterococcus faecium }\end{array}$ \\
\hline 2 & Bag Bugs & Walluski Western Ltd., Astoria, OR & $\begin{array}{l}\text { Lactobacillus plantarum } \\
\text { Enterococcus faecium } \\
\text { Pediococcus pentosaceus }\end{array}$ \\
\hline 4 & Biomax LB & Chr. Hansen, Milwaukee, WI & $\begin{array}{l}\text { Lactobacillus buchneri } \\
\text { Enterococcus faecium } \\
\text { Lactobacillus plantarum }\end{array}$ \\
\hline 6 & Biotal Plus & Lallemand Animal Nutrition, Milwaukee, WI & $\begin{array}{l}\text { Pediococcus pentosaceus } \\
\text { Lactobacillus plantarum } \\
\text { Propionibacterium freudenreichii }\end{array}$ \\
\hline 3 & Buchneri 500 & Lallemand Animal Nutrition, Milwaukee, WI & $\begin{array}{l}\text { Lactobacillus buchneri } \\
\text { Pediococcus pentosaceus }\end{array}$ \\
\hline 15 & Crop-N-Rich MTD1 & Vita Plus, Madison, WI & Lactobacillus plantarum \\
\hline 2 & Prime SI & VFS, Bakersfield, CA & $\begin{array}{l}\text { Pediococcus pentosaceus } \\
\text { Lactobacillus plantarum }\end{array}$ \\
\hline 3 & Promote SI & Cargill Inc., Brookville, OH & $\begin{array}{l}\text { Lactobacillus plantarum } \\
\text { Pediococcus acidilactici }\end{array}$ \\
\hline 2 & $\begin{array}{l}\text { Feedtech Custom Chop } \\
\text { F20 }\end{array}$ & DeLaval, Vernon Hills, IL & $\begin{array}{l}\text { Lactococcus lactis } \\
\text { Pediococcus pentosaceus } \\
\text { Enterococcus faecium } \\
\text { Lactobacillus plantarum }\end{array}$ \\
\hline 6 & $\begin{array}{l}\text { Sil-All } 4 \times 4 \\
\text { WS } 10 \mathrm{X}\end{array}$ & Alltech, Milwaukee, WI & $\begin{array}{l}\text { Lactobacillus plantarum } \\
\text { Pediococcus acidilactici } \\
\text { Pediococcus pentosaceus } \\
\text { Lactobacillus acidophilus }\end{array}$ \\
\hline 5 & Stage 2 & Vita Plus, Madison, WI & $\begin{array}{l}\text { Lactobacillus buchneri } \\
\text { Pediococcus pentosaceus }\end{array}$ \\
\hline
\end{tabular}


tion rate for $\mathrm{LAB}$ (cfu/g of fresh forage) varied with inoculants.

At the time of collection, the temperature of the inoculant-water mixture and ambient temperature in the area surrounding the applicator tank were measured using a digital thermometer. The $\mathrm{pH}$ of the inoculant-water mixture was also measured using a portable digital $\mathrm{pH}$ meter after calibration in $\mathrm{pH} 7$ and 4 buffers. The amount of time between inoculant rehydration and sample collection and the mixing rate of inoculant and water were obtained from the equipment operator.

Simple linear coefficient of determinations among measurements $(\Delta \mathrm{M}-\mathrm{E}, \mathrm{pH}$, time in the tank, ambient temperature, and tank temperature) were analyzed using the Fit X by Y feature of JMP (SAS Institute Inc., Cary, NC), and relationships were deemed significant when $P \leq 0.05$. The dependent variables were $\Delta \mathrm{M}-\mathrm{E}$ and $\mathrm{pH}$, and the independent variables were ambient temperature, time in the tank, $\mathrm{pH}$ of the inoculant-water mixture, and tank temperature.

\section{RESULTS AND DISCUSSION}

Figure $1 \mathrm{~A}$ shows that no correlation $\left(\mathrm{R}^{2}=0.06\right.$; adjusted $\mathrm{R}^{2}=0.04 ; P=0.09$ ) existed between hours in the tank and $\Delta \mathrm{M}-\mathrm{E}$ for the entire data set. The range in time that inoculants were in the tank before sampling was 0 to $52.5 \mathrm{~h}$, and the range in $\Delta \mathrm{M}-\mathrm{E}$ was -2.74 to 1.98. One shortcoming of this study as a survey is that reported and actual amount of time between inoculant rehydration and sample collection may have varied. However, most of the inoculant-water mixes (83\%) had been rehydrated with water in the applicator tanks for $<10 \mathrm{~h}$ (Figure 1B). For these samples, a negative linear correlation $\left(\mathrm{R}^{2}=0.36\right.$; adjusted $\left.\mathrm{R}^{2}=0.34 ; P<0.0001\right)$ existed between time that the inoculant-water mixes were in the applicators tanks and $\Delta \mathrm{M}-\mathrm{E}$ (Figure 1B). This finding suggests that numbers of viable LAB were declining in the applicator tanks with time after mixing. On average, the $\Delta \mathrm{M}-\mathrm{E}$ at the start was positive and approximately 0.69 , indicating that the numbers of LAB in the tanks averaged more than those theoretically expected based on minimum label guarantees of LAB. However, over the course of $10 \mathrm{~h}$ the regression showed that $\Delta \mathrm{M}-\mathrm{E}$ would be negative and almost -1.0. For an inoculant that suggested a final application rate $100,000 \mathrm{cfu}$ of $\mathrm{LAB} / \mathrm{g}$ of forage, a perfect $\Delta \mathrm{M}-\mathrm{E}$ would be 0 . However, a negative $\Delta \mathrm{M}-\mathrm{E}$ of approximately -1.0 would equate to a theoretical application rate of only about $10,000 \mathrm{cfu} / \mathrm{mL}$.

The $\mathrm{pH}$ of the inoculant-water mixture ranged from 3.5 to 8.2 . A negative relationship was found between the amount of time that the inoculant-water mixture was in the applicator tank before sampling and the $\mathrm{pH}$ of the inoculant-water mixture over time (Figure 2A; $\mathrm{R}^{2}=0.28$; adjusted $\mathrm{R}^{2}=0.27 ; P<0.01$ ), within the first $10 \mathrm{~h}$ in the applicator tank (Figure $2 \mathrm{~B}, \mathrm{R}^{2}=0.21$; adjusted $\mathrm{R}^{2}=0.20 ; P<0.01$ ), suggesting that LAB produced acids in the tanks, lowering the $\mathrm{pH}$. However, $\mathrm{pH}$ of the inoculant-water mix had no effect on $\Delta \mathrm{M}$ - E (Figure $3 ; \mathrm{R}^{2}=0.04$, adjusted $\mathrm{R}^{2}=0.03 ; P=$ $0.14)$, suggesting that a decline in $\mathrm{pH}$ alone was not the primary factor for reduced LAB counts with increasing time in the tanks. This finding is not surprising because the $\mathrm{pH}$ measured in the water mixes would most likely not severely affect the viability of most LAB.

Water temperatures in the sampled tanks ranged from 10 to $54.2^{\circ} \mathrm{C}$ (Figure 4). Of the total number of samples, $60 \%$ had positive values of $\Delta \mathrm{M}-\mathrm{E}$ above 0 suggesting that more LAB were present than expected based on label guarantees. This finding may be related to manufacturers of silage inoculants commonly formulating inoculants with more than the minimum label guarantee to ensure meeting these levels even
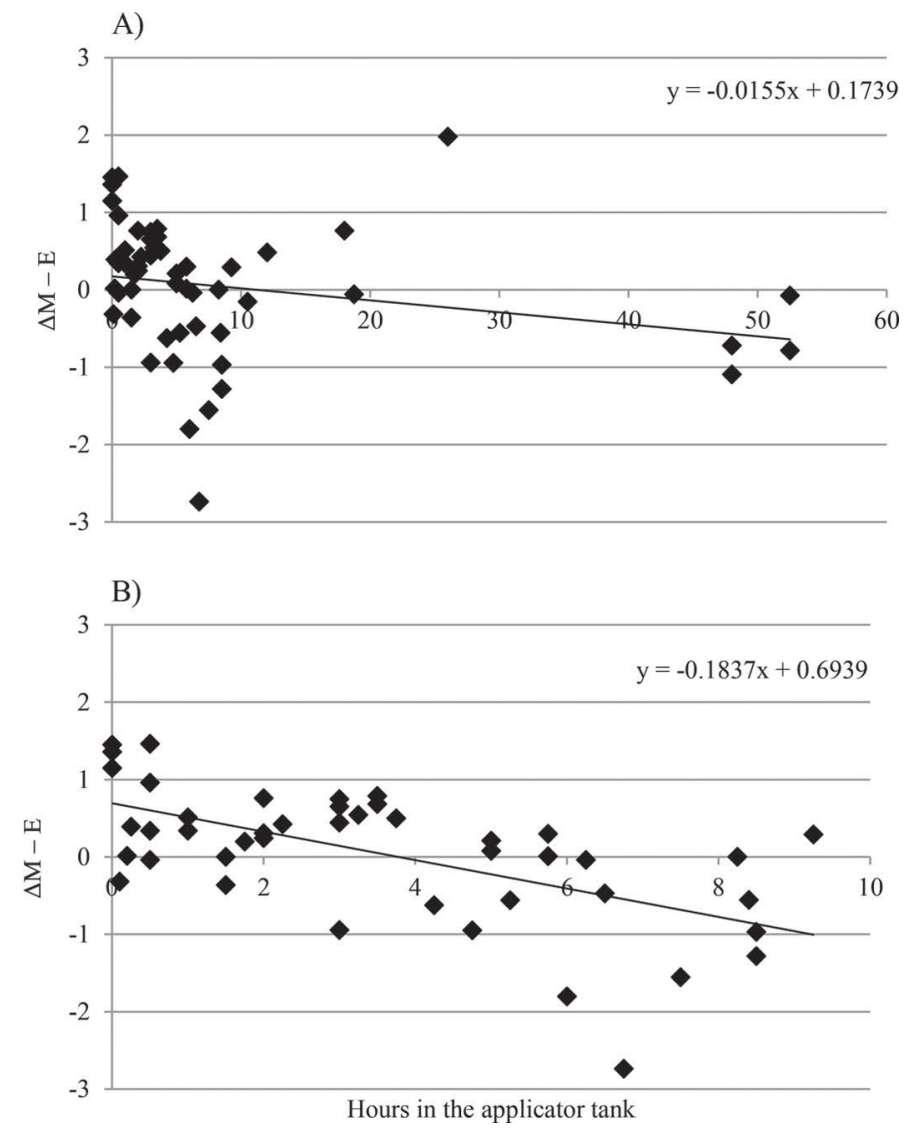

Figure 1. Correlation between time that the inoculant-water mixes were in the applicators tanks and $\Delta \mathrm{M}-\mathrm{E}$ (enumerated cfu of viable lactic acid bacteria minus the calculated cfu of expected lactic acid bacteria) for all samples (A, linear effect, $R^{2}=0.06$, adjusted $R^{2}$ $=0.04, P=0.09)$, and for samples in tanks for only up to $10 \mathrm{~h}(\mathrm{~B}$, linear effect, $\mathrm{R}^{2}=0.36$; adjusted $\left.\mathrm{R}^{2}=0.34, P<0.0001\right)$. 


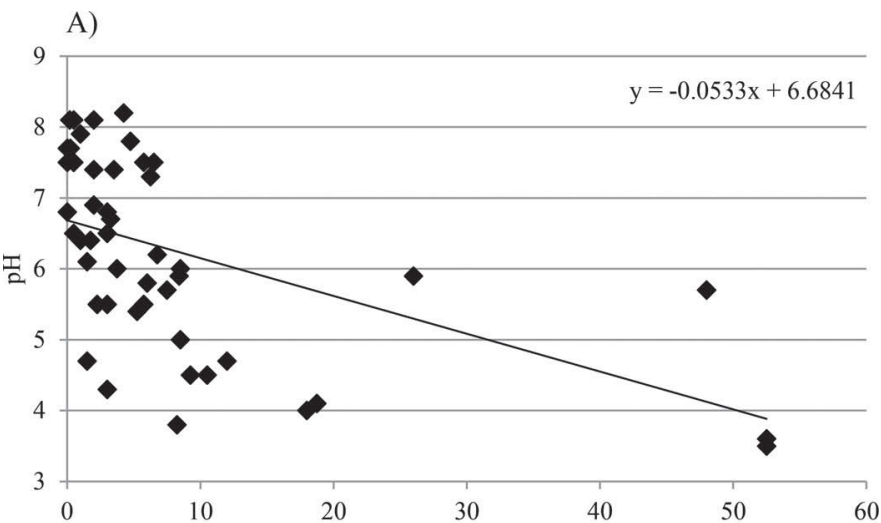

B)

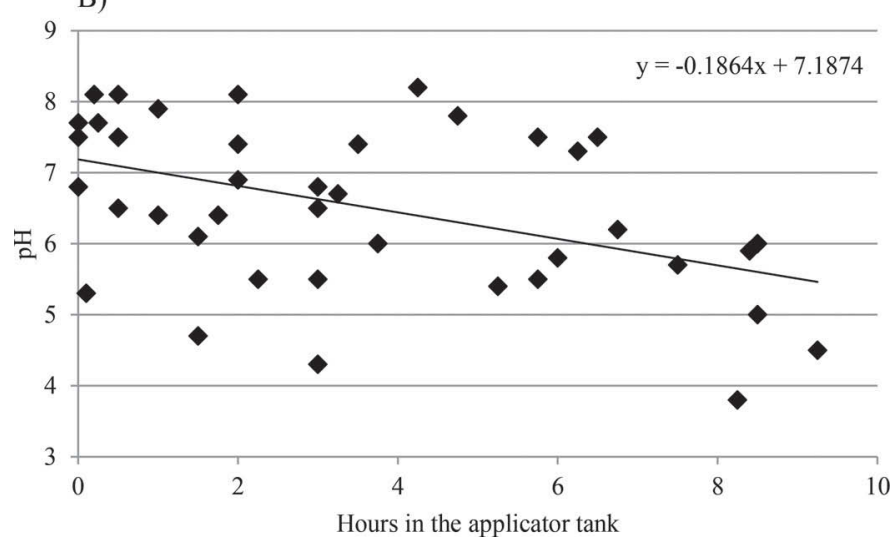

Figure 2. Relationship between the amount of time that the inoculant-water mixture was in the applicator tank before sampling and the $\mathrm{pH}$ of the inoculant-water mixture for all samples (A, linear effect, $\mathrm{R}^{2}=0.28$; adjusted $\mathrm{R}^{2}=0.27 ; P<0.01$ ), and for samples in tanks for only up to $10 \mathrm{~h}$ ( $\mathrm{B}$, linear effect, $\mathrm{R}^{2}=0.21$; adjusted $\mathrm{R}^{2}=0.20$, $P<0.01)$.

after prolonged (months) periods of storage because a drop in viable numbers of LAB is inevitable with time in storage. Unfortunately, numbers of bacteria in the inoculant packets were not measured before mixing,

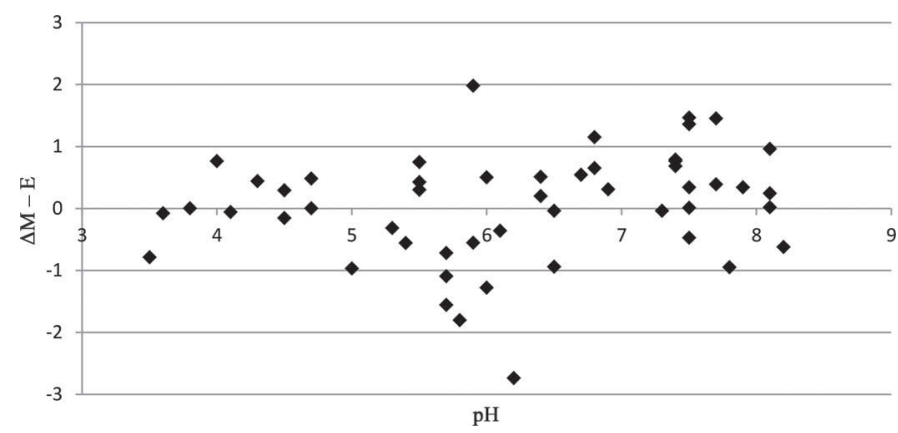

Figure 3. Relationship between the $\mathrm{pH}$ and $\Delta \mathrm{M}-\mathrm{E}$ (enumerated cfu of viable lactic acid bacteria minus the calculated cfu of expected lactic acid bacteria) in the inoculant-water mixture (linear effect, $\mathrm{R}^{2}$ $=0.04$; adjusted $\mathrm{R}^{2}=0.03 ; P=0.14$ ). which could have affected starting $\Delta \mathrm{M}-\mathrm{E}$. Overall, the temperatures of the inoculant-water mixtures were negatively correlated with $\Delta \mathrm{M}-\mathrm{E}\left(\mathrm{R}^{2}=0.39\right.$; adjusted $\left.\mathrm{R}^{2}=0.37, P<0.01\right)$. If the $\Delta \mathrm{M}-\mathrm{E}$ for a sample was -0.3 , the final application rate would be $50 \%$ less than the theoretical suggested dose. Thirty percent of the total samples fell into this category. Seven of 10 samples whose water temperature was above $33.3^{\circ} \mathrm{C}$ had $\Delta \mathrm{M}-\mathrm{E}$ values lower than -0.3 . Seven of 8 samples whose $\Delta \mathrm{M}-\mathrm{E}$ were at least -0.95 or more lower than expected (equivalent to about 1 or more log concentration less than expected) had water temperatures above $35^{\circ} \mathrm{C}$. The negative correlation between water temperature and $\Delta \mathrm{M}-\mathrm{E}$ agrees with the findings of Mulrooney and Kung (2008). They incubated various microbial inoculants in water at temperatures of $30,35,40$, or $45^{\circ} \mathrm{C}$. Within $3 \mathrm{~h}$, significant reductions occurred in viable counts of LAB for $1,2,4$, and 5 of the 6 inoculants tested at the respective temperatures. Storing silages at relatively high temperatures ranging from 30 to $35^{\circ} \mathrm{C}$ (compared with lower temperatures) has had negative consequences on lactic acid fermentations in silages (Weinberg et al., 2001; Kim and Adesogan, 2006), suggesting that LAB can also be stressed at moderately high temperatures in the silo. Under nutrient limiting conditions some LAB are more susceptible to heat stress (Spinks et al., 2006). Thus, it is not surprising that high temperatures in inoculant tanks can affect the viability of LAB. In the current study, environmental temperature ranged from 18.3 to $36^{\circ} \mathrm{C}$. No relationship existed between ambient environmental temperature and $\Delta \mathrm{M}-\mathrm{E}$ (Figure $5, \mathrm{R}^{2}$ $=0.01, P=0.44)$ or between temperature of the inoculant-water mix and time in the applicator tank (data not shown, $\mathrm{R}^{2}=0.01 ; P=0.43$ ). These findings suggest that neither absorption of heat from the sun nor ambient temperature was a major factor resulting in elevated water temperatures. However, we were unable to determine if relationships existed between type or color of the applicator tanks and $\Delta \mathrm{M}-\mathrm{E}$ because the numbers of tanks in different color categories or types of applicators were small. However, based our personal observations, high water temperatures and low LAB counts appeared to be most associated with applicator tanks absorbing heat directly from the choppers. The $\Delta \mathrm{M}-\mathrm{E}$ was severely negative for only one Dohrmann applicator tank (insulated) whose source of mixing water was a large external tank on the farm that had absorbed ambient heat from the sun (data not shown).

Variables out of our control could have affected the calculation of $\Delta \mathrm{M}-\mathrm{E}$ in our study. For example, errors could have been made in mixing rates that would have affected $\Delta \mathrm{M}-\mathrm{E}$, but we assumed that such errors were nonbiased and actual numbers of viable bac- 


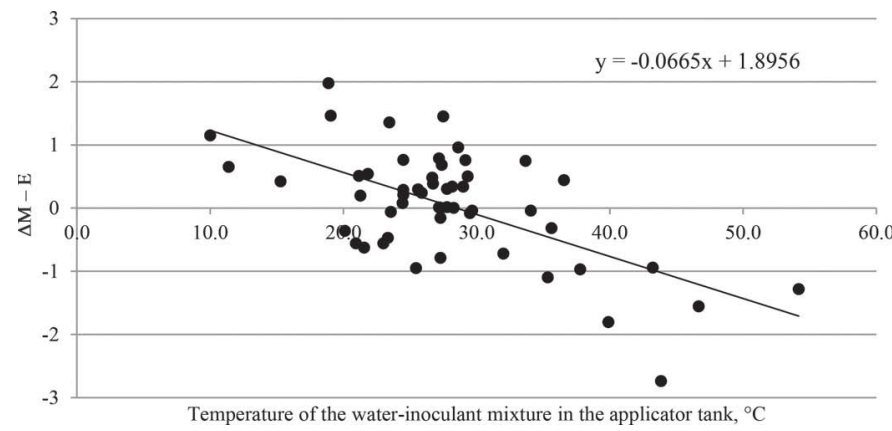

Figure 4. Relationship between the temperature of the inoculantwater mixture in the applicator tank and $\Delta \mathrm{M}-\mathrm{E}$ (enumerated cfu of viable lactic acid bacteria minus the calculated cfu of expected lactic acid bacteria) in the inoculant-water mixture (linear effect, $\mathrm{R}^{2}=0.39$; adjusted $\left.\mathrm{R}^{2}=0.37 ; P<0.01\right)$.

teria in the inoculants used was not quantified. In the study by Mulrooney and Kung (2008), some microbial inoculants were clearly more resistant to heat stress in water than others. Thus, not all inoculants may behave similarly to heat stress in applicator tanks.

\section{CONCLUSIONS}

Temperatures of inoculant-water mixes should be regularly monitored to ensure that they do not exceed about $35^{\circ} \mathrm{C}$ because the numbers of viable LAB may potentially be reduced. Placing tanks to minimize absorption of heat from choppers and avoiding the use of hot water for mixing the inoculants should be considered by operators. In addition, more research is warranted to determine the length of time that inoculants remain stable in applicator tanks. Data from the current study showed a negative correlation between time in the applicator tank and $\Delta \mathrm{M}-\mathrm{E}$ for the first 10 -h period. This finding could have been caused by the tanks absorbing heat from the choppers throughout the day, resulting in elevated water temperatures that reduced the number of viable LAB. Thus, if tanks are absorbing heat from the choppers, both prolonged time of make-up and high temperature of the water mix could be detrimental to the final application rate.

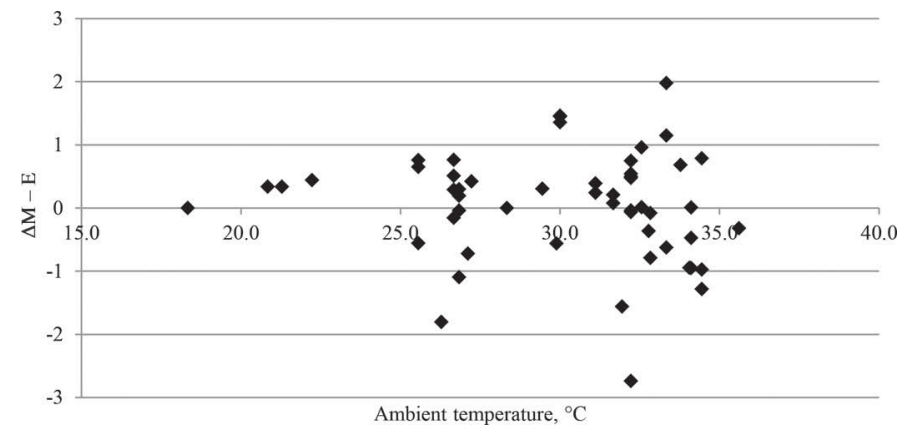

Figure 5. Relationship between the ambient temperature at the time of sampling and $\Delta \mathrm{M}-\mathrm{E}$ (enumerated cfu of viable lactic acid bacteria minus the calculated cfu of expected lactic acid bacteria) in the inoculant-water mixture (linear effect, $\mathrm{R}^{2}=0.01$; adjusted $\mathrm{R}^{2}=$ $0.01 ; P=0.44)$.

\section{ACKNOWLEDGMENTS}

The authors thank Chris Wacek-Driver, formerly employed by Vita Plus Corporation (Madison, WI) and Ron Kuber, Connor Marketing (Fresno, CA) for assisting with collection of samples from farms. We also thank the dairy farmers and custom choppers that allowed us to sample their tanks.

\section{REFERENCES}

Kim, S. C., and A. T. Adesogan. 2006. Influence of ensiling temperature, simulated rainfall, and delayed sealing on fermentation characteristics and aerobic stability of corn silage. J. Dairy Sci. 89:3122-3132.

Muck, R. E. 2010. Silage microbiology and its control through additives. Rev. Bras. Zootec. 39:183-191.

Mulrooney, C. N., and L. Kung Jr.. 2008. The effect of water temperature on the viability of silage inoculants. J. Dairy Sci. 91:236-240.

Spinks, A. T., R. H. Dunstan, T. Harrison, P. Coombes, and G. Kuczera. 2006. Thermal inactivation of water-borne pathogenic and indicator bacteria at sub-boiling temperatures. Water Res. 40:1326-1332.

Stokes, M. R., and J. Chen. 1994. Effects of an enzyme-inoculant mixture on the course of fermentation of corn silage. J. Dairy Sci. 77:3401-3409

Weinberg, Z. G., G. Szakacs, G. Ashbell, and Y. Hen. 2001. The effect of temperature on the ensiling process of corn and wheat. J. Appl. Microbiol. 90:561-566. 